Pacific Northwest

National Laboratory

Operated by Battelle for the

U.S. Department of Energy

\section{Canyon Disposal Initiative - Numerical Modeling of Contaminant Transport from Grouted Residual Waste in the 221-U Facility (U Plant)}

\author{
M. L. Rockhold \\ M. D. White \\ E. J. Freeman
}

October 2004

Prepared for the U.S. Department of Energy under Contract DE-AC06-76RL01830 


\title{
DISCLAIMER
}

This report was prepared as an account of work sponsored by an agency of the United States Government. Neither the United States Government nor any agency thereof, nor Battelle Memorial Institute, nor any of their employees, makes any warranty, express or implied, or assumes any legal liability or responsibility for the accuracy, completeness, or usefulness of any information, apparatus, product, or process disclosed, or represents that its use would not infringe privately owned rights. Reference herein to any specific commercial product, process, or service by trade name, trademark, manufacturer, or otherwise does not necessarily constitute or imply its endorsement, recommendation, or favoring by the United States Government or any agency thereof, or Battelle Memorial Institute. The views and opinions of authors expressed herein do not necessarily state or reflect those of the United States Government or any agency thereof.

\author{
PACIFIC NORTHWEST NATIONAL LABORATORY \\ operated by \\ BATTELLE \\ for the \\ UNITED STATES DEPARTMENT OF ENERGY \\ under Contract DE-AC05-76RL01830
}

Printed in the United States of America
Available to DOE and DOE contractors from the Office of Scientific and Technical Information,
P.O. Box 62, Oak Ridge, TN 37831-0062;
ph: (865) 576-8401
fax: (865) 576-5728
email: reports@adonis.osti.gov

\author{
Available to the public from the National Technical Information Service, \\ U.S. Department of Commerce, 5285 Port Royal Rd., Springfield, VA 22161 \\ ph: (800) 553-6847 \\ fax: (703) 605-6900 \\ email: orders@ntis.fedworld.gov \\ online ordering: http://www.ntis.gov/ordering.htm
}

This document was printed on recycled paper. 


\title{
Canyon Disposal Initiative - Numerical Modeling of Contaminant Transport from Grouted Residual Waste in the 221-U Facility (U Plant)
}

\author{
M. L. Rockhold \\ M. D. White \\ E. J. Freeman
}

October 122004

Prepared for

Fluor Hanford Co.

Pacific Northwest National Laboratory

Richland, Washington 99352 


\section{Executive Summary}

This report documents initial numerical analyses conducted by Pacific Northwest National Laboratory (PNNL) to provide support for a feasibility study on decommissioning the 221-U canyon building at Hanford. The 221-U facility is the first of the major canyon buildings to be decommissioned. The specific objective of this modeling effort was to provide estimates of potential rates of migration of residual contaminants out of the 221- $\mathrm{U}$ facility during the first 40 years after decommissioning. The results indicate that under the simulated conditions, none of the modeled radionuclides that are known to be part of the inventory (Jacques 2001) migrated beyond the concrete structure of the facility.

Contaminant release from the canyon buildings should be diffusion controlled at early times. Advection is expected to become much more important at later times, after contaminants have diffused out of the facility and into the surrounding environment. After contaminants have diffused out of the facility, surface infiltration covers will potentially become very important for mitigating further transport of contaminants in the underlying vadose zone and groundwater. 


\section{Contents}

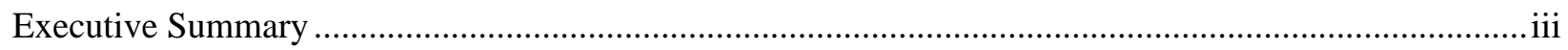

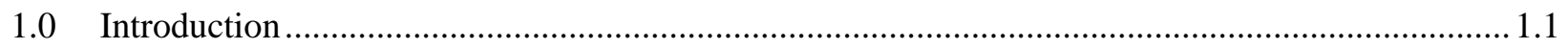

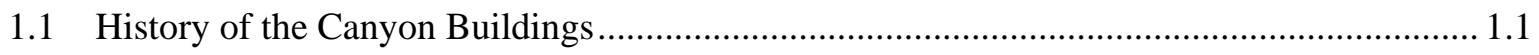

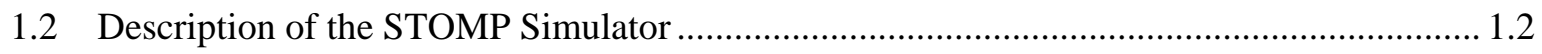

2.0 Modeling Assumptions and Initial and Boundary Conditions ................................................ 2.1

2.1 Hydraulic and Transport Properties............................................................................. 2.3

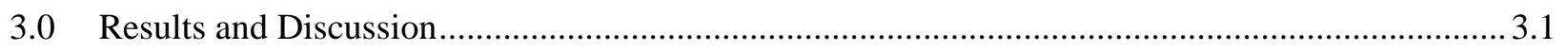

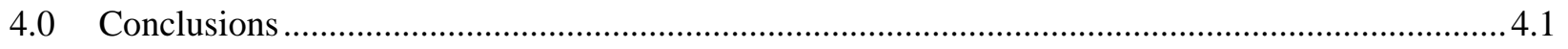

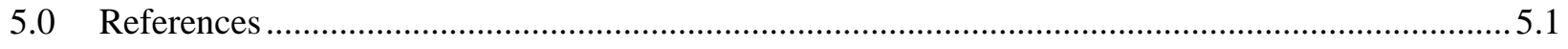

Appendix A - Radionuclide Inventories Used for Initial Conditions in STOMP Simulations ................ A.1

Appendix B - Physical, Hydraulic, and Transport Parameters Used for STOMP Simulations...................1

\section{Figures}

1 Representative Cross-Section Through the Decommissioned 221-U Facility Showing Physical Dimensions and Assumed Locations of Contaminants ................................................................. 2.1

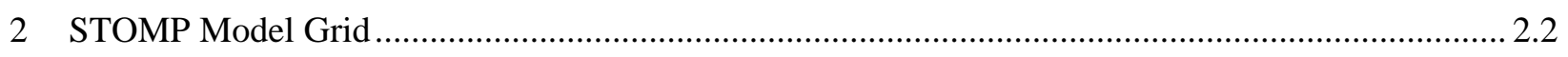

3 Simulated Total Concentrations of ${ }^{137} \mathrm{Cs}$ and ${ }^{239} \mathrm{Pu}$ in the Vicinity of the Drain Header at Times of 0,10 , and 40 Years.................................................................................................... 3.3

4 Simulated Aqueous Saturation Distributions at 0, 10, and 40 Years................................................ 3.4

\section{Tables}

1 Mass Fraction of Total Inventory Contained in Grout, Concrete, and Soil..................................... 3.2 


\subsection{Introduction}

This letter report documents initial numerical analyses conducted by PNNL to provide support for a feasibility study on decommissioning of the canyon buildings at Hanford. The 221-U facility is the first of the major canyon buildings to be decommissioned. The specific objective of this modeling effort was to provide estimates of potential rates of migration of residual contaminants out of the 221-U facility during the first 40 years after decommissioning. If minimal contaminant migration is predicted to occur from the facility during this time period, then the structure may be deemed to provide a level of groundwater protection that is essentially equivalent to the liner and leachate collection systems that are required at conventional landfills.

This report is organized as follows. A brief history is given of the canyon buildings at Hanford, followed by a summary of recent characterization activities at the 221-U facility. Data from these characterization activities were used to estimate the initial inventory of contaminants in the facility. Simulations of contaminant transport were conducted using the numerical model STOMP. A brief description is given of the code, followed by discussion on the physical, hydraulic, and transport properties and model parameters that were used to represent the engineered materials and sediments around the facility. The modeling assumptions, grid specifications, and the boundary and initial conditions are then described. The simulation results are then presented, followed by conclusions. The assumed initial radionuclide inventories and the physical, hydraulic, and transport parameters that were used in the modeling are tabulated in the appendices.

\subsection{History of the Canyon Buildings}

The following description of the history of the canyon buildings was taken from Jacques (2001, p. 2-1). There are five major canyon buildings on the Hanford Site, constructed in the early to mid-1940s in support of World War II plutonium production. These buildings are referred to as "canyon buildings" due to their immense size and the canyon-like appearance of their interiors. These buildings are the 221-U facility (U Plant), the 221-T facility (T Plant), and the 202-S facility (REDOX or S Plant), all located in the 200 West Area, and the 221-A facility (PUREX) and 221-B facility (B Plant), which are located in the 200 East Area.

The B Plant, T Plant, and U Plant were identical bismuth-phosphate chemical separations plants that were built to extract plutonium from fuel rods irradiated in the Hanford Site's production reactors. The capacity of the B Plant and T Plant were apparently sufficient to meet production goals, so the U Plant was never actually used to extract plutonium from fuel elements. Instead, it was used to train B Plant and T Plant operators until 1952, when it was converted to the tributyl phosphate (TBP) process to recover uranium from high-level bismuth-phosphate wastes.

The 221-U facility TBP process recovered residual uranium from B Plant and T Plant wastes that had been stored in tank farms. The waste tanks were sluiced with their own supernatant to produce slurry which was then pumped to the 221-U facility through underground transfer lines. A counter-current extraction column used organic solutions of TBP in kerosene to preferentially attract uranium, separating it from other fission products and small amounts of plutonium. Uranium was then stripped back into the aqueous phase of a second column. The uranyl nitrate was converted to uranium-trioxide $\left(\mathrm{U}_{3}\right)$ by

calcinations at high temperatures. Underground transfer lines were used to pump TBP intermediate-level 
liquid wastes from the 221-U facility to cribs and trenches located in the 200 East Area, about $4.8 \mathrm{~km}$ from B Plant. The non-TBP waste from the 221-U facility was disposed in nearby cribs, trenches, reverse wells, and the U Pond. High level waste from the facility was transferred to the 241-U Tank Farm.

The 221-U facility was placed in standby mode in 1958 and was subsequently retired.

All TBP process hardware was cleaned in 1957 and remains in place. Decontamination and reclamation activities occurred in the building from 1958 to 1964. The building is now inactive and contains legacy equipment. The focus of the current study is on the decommissioning of the 221-U facility.

\subsection{Description of the STOMP Simulator}

Numerical simulations of contaminant transport from the 221-U facility were conducted using the STOMP simulator (White and Oostrom 2003). STOMP is a numerical model that simulates heat and mass transfer through multiple fluid phases in porous media systems. STOMP is currently used to support several different performance and risk assessment activities across the Hanford Site (e.g., tank farm field investigation, etc.) and has undergone extensive testing and verification with comparisons of simulation results to analytical solutions and laboratory and field data (http://www.pnl.gov/etd/stomp/).

Mode 1 of STOMP was used in this work. This mode solves a single governing equation for the mass balance of liquid water under isothermal conditions, and separate mass balance equations for the advection and diffusion/dispersion of aqueous-phase solutes. Complete descriptions of the governing equations and numerical methods used in STOMP are given by White and Oostrom (1996). 


\subsection{Modeling Assumptions and Initial and Boundary Conditions}

The decommissioning process is expected to involve cutting the roofs off of the canyon buildings, entombing the process cells, piping and electrical galleries, drains, and any residual contamination that may be contained in the buildings with grout, and then placing infiltration barriers over them. The focus of this initial modeling effort was on the near-field system, so surface infiltration barriers and most of the vadose zone and underlying aquifer were not included in the analyses. Furthermore, it was assumed that the concrete structure of the facility contains no significant cracks or other features that could lead to preferential movement of percolating water through the waste and out of the facility into the surrounding environment.

Figure 1 depicts a representative cross section through the 221-U facility after decommissioning, showing physical dimensions and the assumed locations of residual contamination (figure provided by Mark Gibson, FHC). An assumed radionuclide inventory was established for use as initial conditions in the modeling based on values obtained from the final 221-U facility characterization report (Jacques, 2001). Four areas of residual contamination are depicted in Figure 1: a 6-inch-thick layer of grout in the bottom of the process cell representing the first lift of poured grout and residuals at the bottom of vessels/equipment; a $1 \frac{1}{2}$-inch-thick layer of contaminated concrete at the base of the process cell underlying the grout; a 2.6-foot-thick layer of grout in the bottom of the ventilation tunnel; and a 2-footdiameter drain header underneath the facility. The assumed inventory in these four areas was provided in a spreadsheet by Mark Gibson (FHC) and was based on the data reported by Jacques (2001). The inventory is given in Tables A.1-A.4 of Appendix A.

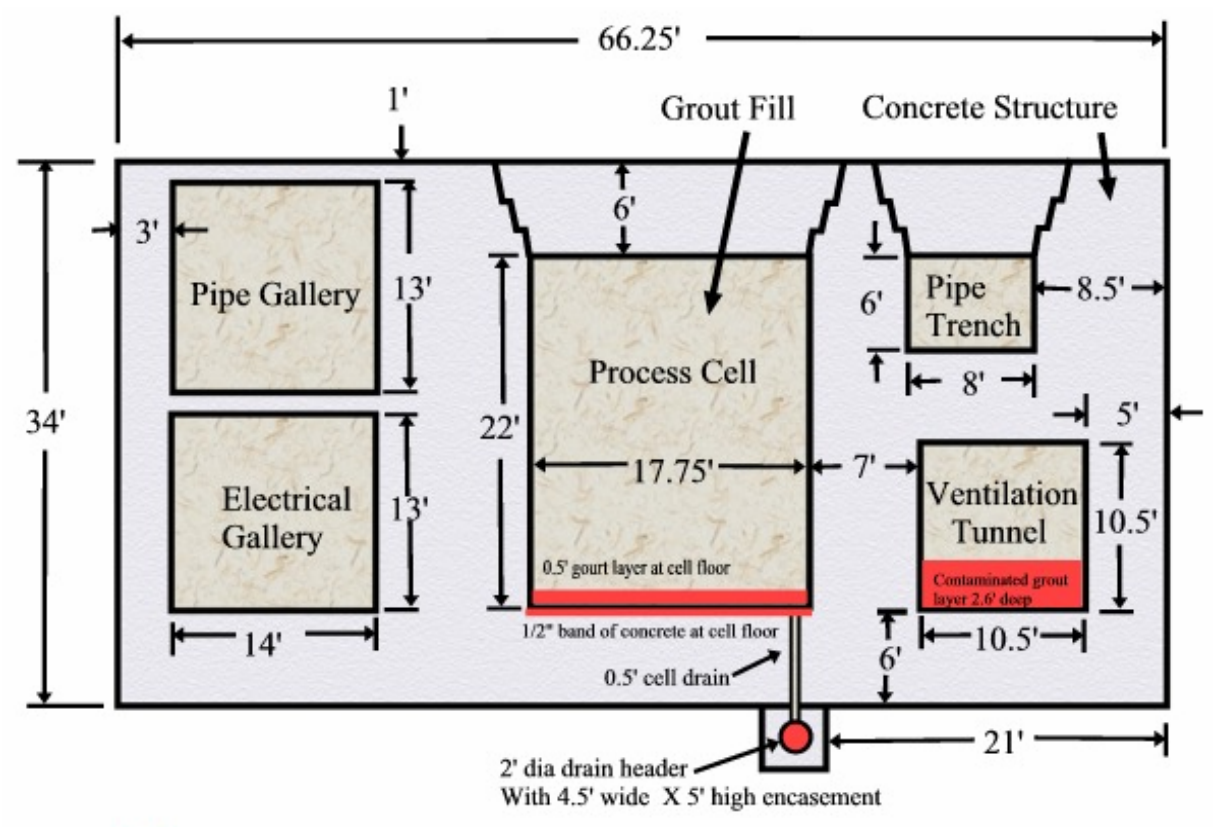

- Red grout areas assumed contaminated for modeling purposes

Figure 1. Representative Cross-Section Through the Decommissioned 221-U Facility Showing Physical Dimensions and Assumed Locations of Contaminants 
A 14-m-high by 1-m-deep by 41-m-wide model domain was discretized to represent the decommissioned facility, as depicted in Figure 2. Buffer regions, $10.36 \mathrm{~m}$ wide, were included on either side of the facility to account for backfilled soil materials that were put in place after its initial construction (above sloping lines in Figure 2). A 30-cm-thick compacted soil material was designated for the region immediately under the facility to represent compacted sediments underlying the structure. A 1-m-thick buffer region of Hanford soil materials was included in the model domain beneath the drain header encasement. A 1-m-thick region spanning the top of the model domain was assigned properties of gravel to allow for diversion of infiltrating water across the top of the underlying concrete structure. Node spacings in the model grid were variable, ranging from 1.27 to $60.96 \mathrm{~cm}$ in the vertical direction, and from 5 to $100 \mathrm{~cm}$ in the horizontal direction, with the finest discretization at the base of the grouted process cells and in the region representing the drain header. The regions of continuous red color in Figure 2 are areas where the grid is more finely discretized. Note that the circular, 2-ft-diameter drain header depicted in Figure 1 was represented in the model as a rectangular, $0.551 \mathrm{~m}$ by $0.554 \mathrm{~m}$ region (see Figure 2), with approximately the same cross-sectional area as the drain header.

The initial conditions that were assigned in the model simulations were a uniform soil-moisture tension of $100 \mathrm{~cm}$ everywhere except for the grouted regions, depicted in Figure 1, which were assumed to be initially saturated ( $0 \mathrm{~cm}$ tension). The initial concentrations of the radionuclides in each of the contaminated areas (red regions in Figure 1) are given in Tables A.1-A.4. The upper boundary was assigned a flux of $8 \mathrm{~cm} / \mathrm{yr}$ ( $\sim 50 \%$ of average annual precipitation) for the first 10 years of the simulation to represent an open period prior to construction of a surface infiltration barrier. Thereafter, a flux of $0.1 \mathrm{~cm} / \mathrm{yr}$ was specified to represent reduced infiltration rates after placement of the infiltration barrier (Rockhold et al., 1995). The lateral boundaries were specified as no-flow boundaries for water and solutes. The bottom boundary was specified as a unit hydraulic gradient (gravity drainage) boundary for water and an outflow boundary for solutes.

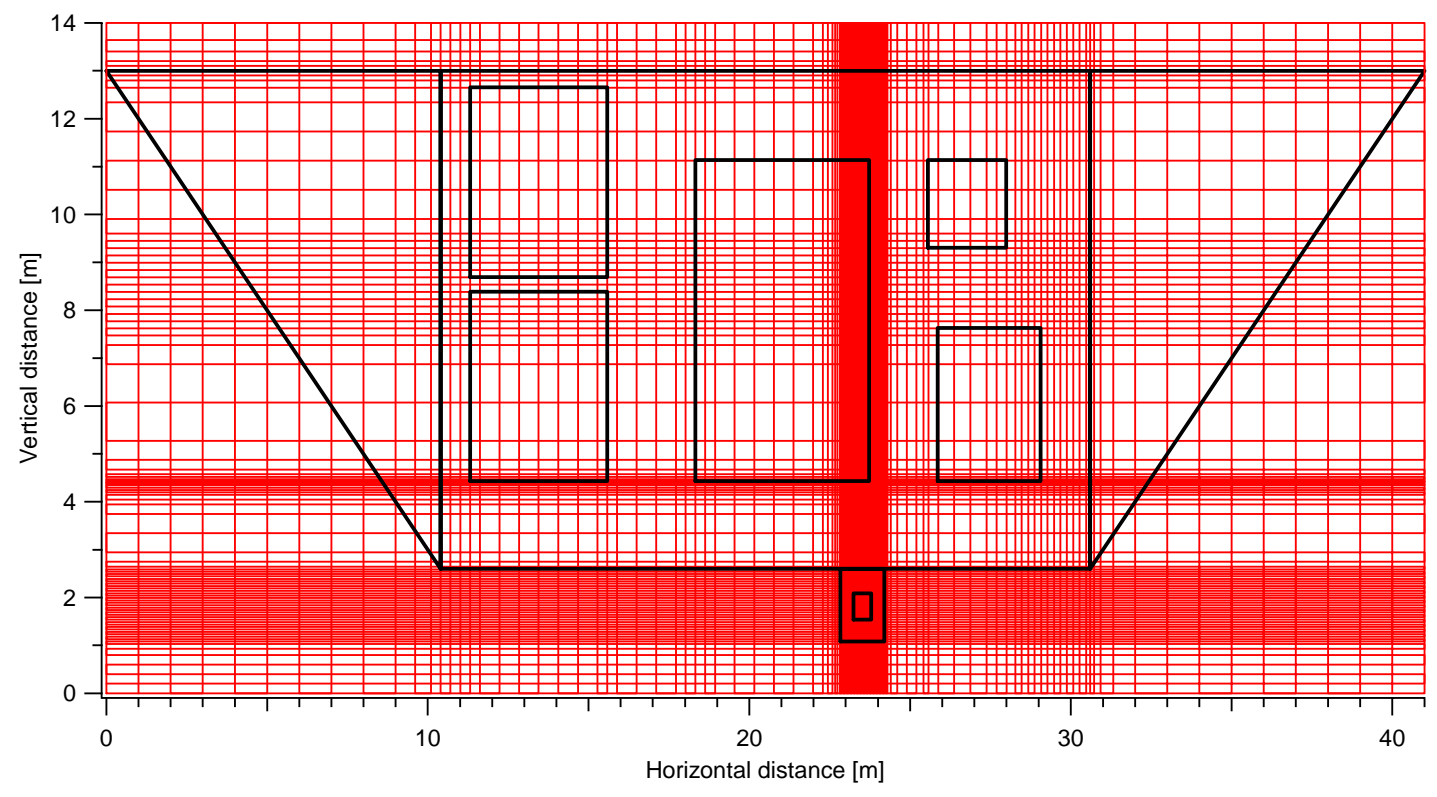

Figure 2. STOMP Model Grid 


\subsection{Hydraulic and Transport Properties}

The constitutive permeability-saturation-capillary pressure relations for the materials in this study were represented by the following functions (van Genuchten, 1978; Mualem, 1976)

$$
\theta=\theta_{r}+\left(\theta_{S}-\theta_{r}\right)\left[1+(\alpha h)^{n}\right]^{-m}
$$

where $\theta$ is the volumetric water content, $\theta_{s}$ is the saturated water content or porosity, $\theta_{r}$ is the residual or irreducible water content, $\alpha, n$, and $m$ are empirical fitting parameters, and $h$ is the soil-moisture tension, which is related to the capillary pressure. Unsaturated hydraulic conductivity was described by

$$
K=K_{s} \frac{\left\{1-(\alpha h)^{n-1}\left[1+(\alpha h)^{n}\right]^{-m}\right\}^{2}}{\left[1+(\alpha h)^{n}\right]^{m / 2}}
$$

where $K_{s}$ is the hydraulic conductivity of the porous media when completely filled with water, and $\mathrm{m}=1$ $1 / \mathrm{n}$.

Parameters representing the physical and hydraulic properties of the backfill soil, compacted soil under the facility, and the building concrete were taken from Meyer and Serne (1999). Physical and hydraulic properties for grout and Hanford formation sediments representative of those underlying the 221-U facility were taken, in part, from Rockhold et al. (1993). The properties of the "structural" grout that will be used to fill the chambers of the 221-U facility are assumed to be different than those of the "tank" grout reported by Rockhold et al. (1993). However the actual properties of the structural grout will be determined during remedial design for the CDI project. For the purposes of this feasibility study, the bulk density, $\rho_{b}$, of the structural grout was assumed to be $2.4 \mathrm{~g} / \mathrm{cm}^{3}$ (personal communication from Mark Gibson, FHC), and the particle density, $\rho_{p}$, was assumed to be the same as concrete, $2.63 \mathrm{~g} / \mathrm{cm}^{3}$ (Meyer and Serne, 1999), resulting in a porosity of 0.087. The remaining hydraulic parameters for the grout were assumed to be the same as those given by Rockhold et al. (1993). The physical and hydraulic parameters used to represent each of the material types used in the model simulations are tabulated in Appendix B of this report.

Effective aqueous-phase diffusion coefficients were estimated from (Kemper and van Schaik, 1966)

$$
D_{e}(\theta)=D_{a b} a \exp (b \theta)
$$

where $D_{a b}$ is the diffusion coefficient for the species in water, and $a$ and $b$ are empirical parameters. Diffusion and sorption coefficients for the natural and engineered materials were taken from Kincaid et al. (1995; Tables 3.14 and 3.15). Half-lives, $t_{1 / 2}$, for the radionuclides of interest were taken from Lide (1996). Half-lives and diffusion and sorption coefficients are tabulated in Appendix B. Some additional data that were reviewed for consistency and that may be useful in future modeling studies are given by Mattigod et al. (2001) and Whiting and Walitt (1988). 


\subsection{Results and Discussion}

The primary objective of this study was to estimate rates of radionuclide migration out of the 221-U facility into the surrounding soil environment. All of the radionuclides that were modeled are expected to adsorb to varying extents in the grout and concrete, as indicated by the assigned $K_{d}$ values given in Tables B.4 and B.5. The simulated mass fractions of the total inventory of each radionuclide in grout, concrete, and soil are summarized in Table 1 for times of 0 (initial condition), 10, and 40 years. These results indicate that under the simulated conditions, none of the radionuclides that are known to be part of the inventory (Jacques, 2001) migrated outside of the concrete structure during the 40-year time period of interest. However, these results clearly indicate that the radionuclides do diffuse out of the grout and into the surrounding concrete. Given enough time, it is expected that they will migrate out of the concrete and into the surrounding soil.

The shortest distance between any of the contaminated areas and the soil environment outside of the concrete structure of the facility is around the drain header. If diffusion is the dominant mechanism for contaminant transport out of the facility, the soil environment around the drain header is likely to become contaminated before other areas. Figure 3 depicts simulated concentration distributions in the vicinity of the drain header for ${ }^{137} \mathrm{Cs}$ and ${ }^{239} \mathrm{Pu}$ at times of 0,10 , and 40 years. The rate of migration of ${ }^{137} \mathrm{Cs}$ out of the grout is greater than that of ${ }^{239} \mathrm{Pu}$ due to the differences in $\mathrm{K}_{\mathrm{d}}$ values (see Table B.5).

One of the initial concerns prior to the initiation of this modeling effort was that the lack of a surface infiltration cover during the early stages of decommissioning could result in enhanced transport of contaminants from the facility. Figure 4 depicts aqueous saturation distributions at times of 0,10 , and 40 years. Relatively wet initial conditions were specified in the model simulation, which resulted in some water draining out of the backfill material after 10 years, in spite of the relatively high surface recharge rate that was assumed $(8 \mathrm{~cm} / \mathrm{yr})$. Although difficult to see in Figure 4 , the simulated aqueous saturations increase in the gravel above the concrete between times of 0 and 10 years. Water infiltrating over the top of the facility is diverted laterally, and down its sides, resulting in higher aqueous saturations at the lower corners of the facility. After a simulation period of 10 years, the surface boundary flux for water is changed from $8 \mathrm{~cm} / \mathrm{yr}$ to $0.1 \mathrm{~cm} / \mathrm{yr}$. This results in lower aqueous saturations at later times, particularly in the backfull material.

Figure 4 indicates that the saturations in the grout and concrete remain at or near 1.0 (fully water saturated) for the entire 40-year simulation period, due to the hydraulic properties that were assumed, and the specified initial conditions. For the purposes of this feasibility study isothermal conditions were also assumed. However, if there is a significant heat load associated with radioactive decay, or exothermic reactions during curing of the grout, then this could induce some movement of water out of the grout.

Although the simulation results indicate that there are significant differences in the water saturation distributions (and velocities) during the open and covered periods (high and low infiltration rates, respectively), these appear to be of no practical consequence during the 40-year simulation period of interest, at least for the radionuclides that were modeled. Contaminant release from the facility is diffusion controlled at early times. Therefore the advective flux of water around the facility has no significant impact on the initial release of contaminants. Advection is expected to become much more important at later times, however, after the contaminants have diffused out of the grout and concrete and 
Table 1. Mass Fraction of Total Inventory Contained in Grout, Concrete, and Soil

\begin{tabular}{|c|c|c|c|c|}
\hline Radionuclide & Time [yr] & Grout & Concrete & Soil \\
\hline \multirow[t]{3}{*}{${ }^{60} \mathrm{Co}$} & 0 & $1.000 \mathrm{E}+00$ & $7.742 \mathrm{E}-13$ & $0.000 \mathrm{E}+00$ \\
\hline & 10 & $9.986 \mathrm{E}-01$ & $1.423 \mathrm{E}-03$ & $0.000 \mathrm{E}+00$ \\
\hline & 40 & 9.944E-01 & $5.621 \mathrm{E}-03$ & $0.000 \mathrm{E}+00$ \\
\hline \multirow[t]{3}{*}{${ }^{90} \mathrm{Sr}$} & 0 & $1.000 \mathrm{E}+00$ & 7.337E-10 & $0.000 \mathrm{E}+00$ \\
\hline & 10 & 9.986E-01 & 1.423E-03 & $0.000 \mathrm{E}+00$ \\
\hline & 40 & 9.944E-01 & 5.621E-03 & $0.000 \mathrm{E}+00$ \\
\hline \multirow[t]{3}{*}{${ }^{137} \mathrm{Cs}$} & 0 & $1.000 \mathrm{E}+00$ & $2.352 \mathrm{E}-10$ & $0.000 \mathrm{E}+00$ \\
\hline & 10 & 9.986E-01 & $1.423 \mathrm{E}-03$ & $0.000 \mathrm{E}+00$ \\
\hline & 40 & $9.944 \mathrm{E}-01$ & 5.621E-03 & $0.000 \mathrm{E}+00$ \\
\hline \multirow[t]{3}{*}{${ }^{154} \mathrm{Eu}$} & 0 & 9.878E-01 & $1.220 \mathrm{E}-02$ & $0.000 \mathrm{E}+00$ \\
\hline & 10 & 9.877E-01 & $1.229 \mathrm{E}-02$ & $0.000 \mathrm{E}+00$ \\
\hline & 40 & $9.874 \mathrm{E}-01$ & $1.256 \mathrm{E}-02$ & $0.000 \mathrm{E}+00$ \\
\hline \multirow[t]{3}{*}{${ }^{230} \mathrm{Th}$} & 0 & $0.000 \mathrm{E}+00$ & $1.000 \mathrm{E}+00$ & $0.000 \mathrm{E}+00$ \\
\hline & 10 & $1.456 \mathrm{E}-03$ & $9.985 \mathrm{E}-01$ & $0.000 \mathrm{E}+00$ \\
\hline & 40 & 5.914E-03 & $9.941 \mathrm{E}-01$ & $0.000 \mathrm{E}+00$ \\
\hline \multirow[t]{3}{*}{${ }^{232} \mathrm{Th}$} & 0 & $1.000 \mathrm{E}+00$ & $0.000 \mathrm{E}+00$ & $0.000 \mathrm{E}+00$ \\
\hline & 10 & 9.999E-01 & $1.344 \mathrm{E}-04$ & $0.000 \mathrm{E}+00$ \\
\hline & 40 & 9.995E-01 & $5.244 \mathrm{E}-04$ & $0.000 \mathrm{E}+00$ \\
\hline \multirow[t]{3}{*}{${ }^{234} \mathrm{U}$} & 0 & $1.000 \mathrm{E}+00$ & 6.776E-06 & $0.000 \mathrm{E}+00$ \\
\hline & 10 & 9.999E-01 & $1.412 \mathrm{E}-04$ & $0.000 \mathrm{E}+00$ \\
\hline & 40 & 9.995E-01 & 5.311E-04 & $0.000 \mathrm{E}+00$ \\
\hline \multirow[t]{3}{*}{${ }^{235} \mathrm{U}$} & 0 & $1.000 \mathrm{E}+00$ & $6.905 \mathrm{E}-07$ & $0.000 \mathrm{E}+00$ \\
\hline & 10 & 9.999E-01 & $1.351 \mathrm{E}-04$ & $0.000 \mathrm{E}+00$ \\
\hline & 40 & 9.995E-01 & 5.251E-04 & $0.000 \mathrm{E}+00$ \\
\hline \multirow[t]{3}{*}{${ }^{237} \mathrm{~Np}$} & 0 & 9.581E-01 & 4.186E-02 & $0.000 \mathrm{E}+00$ \\
\hline & 10 & $9.572 \mathrm{E}-01$ & $4.283 \mathrm{E}-02$ & $0.000 \mathrm{E}+00$ \\
\hline & 40 & 9.545E-01 & 4.553E-02 & $0.000 \mathrm{E}+00$ \\
\hline \multirow[t]{3}{*}{${ }^{238} \mathrm{U}$} & 0 & $1.000 \mathrm{E}+00$ & $1.044 \mathrm{E}-06$ & $0.000 \mathrm{E}+00$ \\
\hline & 10 & 9.999E-01 & 1.355E-04 & $0.000 \mathrm{E}+00$ \\
\hline & 40 & 9.995E-01 & 5.255E-04 & $0.000 \mathrm{E}+00$ \\
\hline \multirow[t]{3}{*}{${ }^{238} \mathrm{Pu}$} & 0 & $1.000 \mathrm{E}+00$ & 4.604E-09 & $0.000 \mathrm{E}+00$ \\
\hline & 10 & 9.999E-01 & 6.806E-05 & $0.000 \mathrm{E}+00$ \\
\hline & 40 & 9.997E-01 & $2.720 \mathrm{E}-04$ & $0.000 \mathrm{E}+00$ \\
\hline \multirow[t]{3}{*}{${ }^{239} \mathrm{Pu}$} & 0 & $1.000 \mathrm{E}+00$ & 7.626E-07 & $0.000 \mathrm{E}+00$ \\
\hline & 10 & 9.999E-01 & 6.956E-05 & $0.000 \mathrm{E}+00$ \\
\hline & 40 & 9.997E-01 & 2.755E-04 & $0.000 \mathrm{E}+00$ \\
\hline \multirow[t]{3}{*}{${ }^{240} \mathrm{Pu}$} & 0 & $1.000 \mathrm{E}+00$ & 2.086E-07 & $0.000 \mathrm{E}+00$ \\
\hline & 10 & 9.999E-01 & 6.864E-05 & $0.000 \mathrm{E}+00$ \\
\hline & 40 & 9.997E-01 & 2.736E-04 & $0.000 \mathrm{E}+00$ \\
\hline \multirow[t]{3}{*}{${ }^{241} \mathrm{Am}$} & 0 & $1.000 \mathrm{E}+00$ & $1.626 \mathrm{E}-08$ & $0.000 \mathrm{E}+00$ \\
\hline & 10 & 9.999E-01 & 6.808E-05 & $0.000 \mathrm{E}+00$ \\
\hline & 40 & 9.997E-01 & 2.720E-04 & $0.000 \mathrm{E}+00$ \\
\hline
\end{tabular}



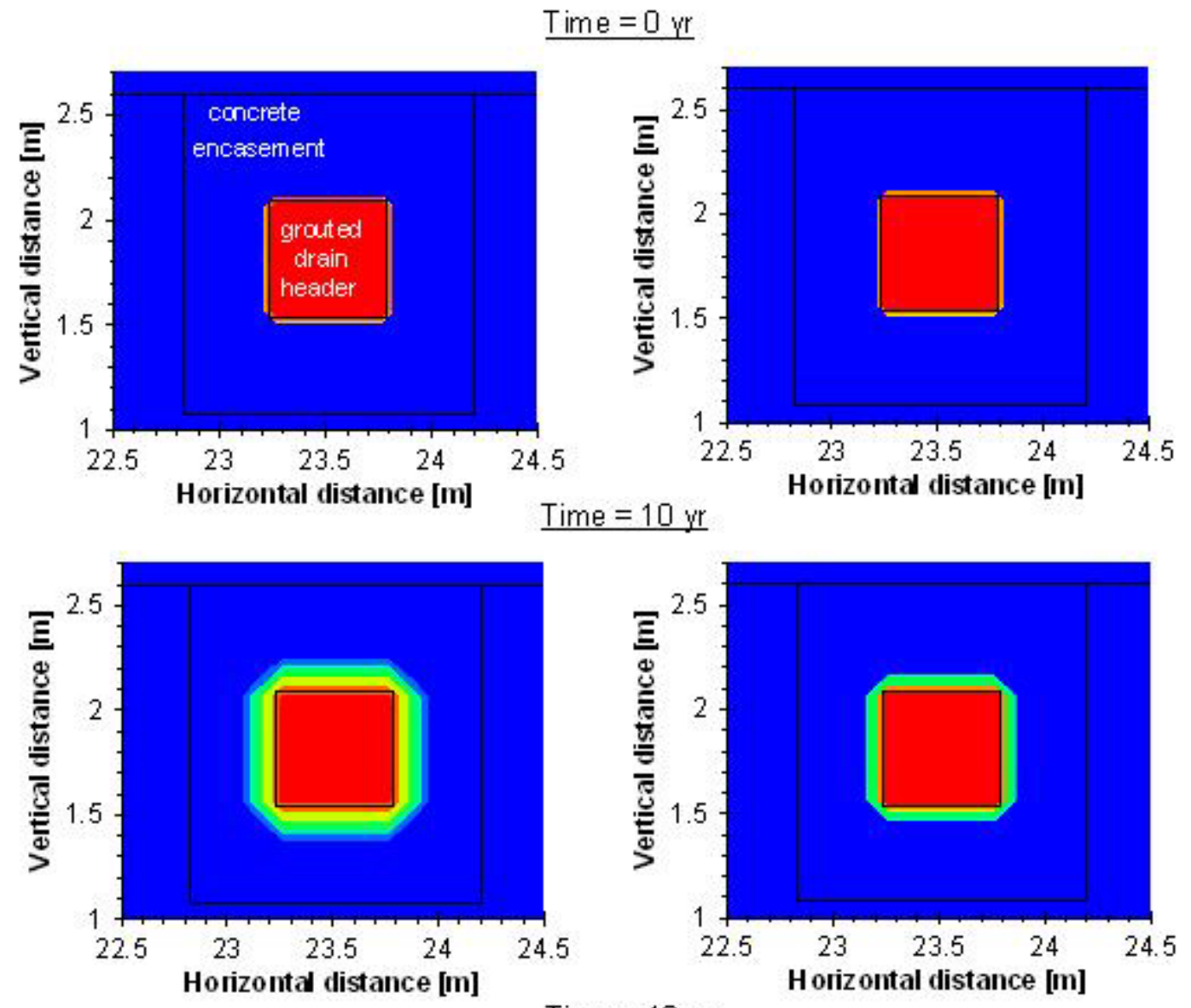

$\underline{\text { Time }}=40 \mathrm{yr}$
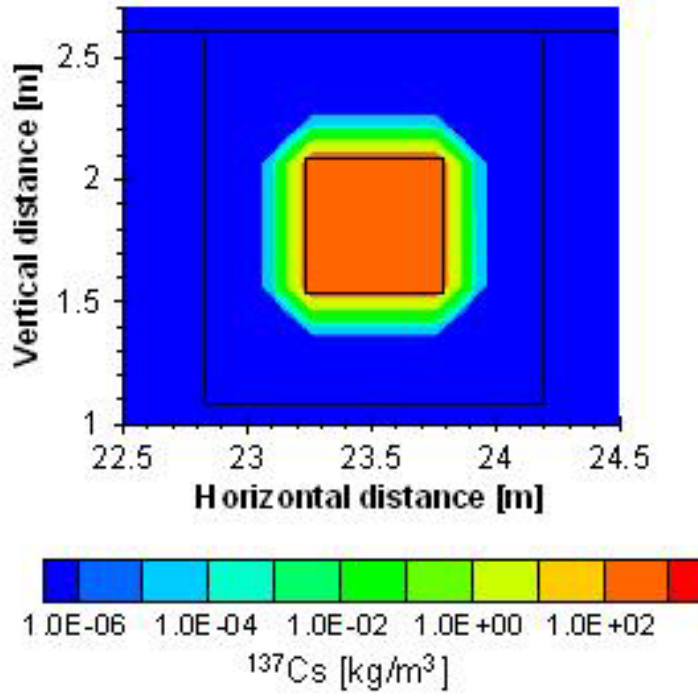
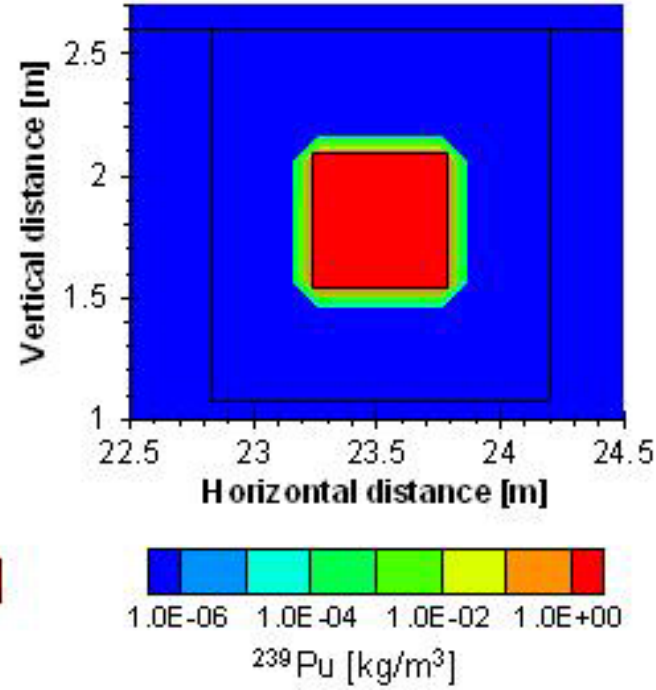

Figure 3. Simulated Total Concentrations $\left[\mathrm{kg} / \mathrm{m}^{3}\right]$ of ${ }^{137} \mathrm{Cs}$ (left column) and ${ }^{239} \mathrm{Pu}$ (right column) in the Vicinity of the Drain Header at Times of 0, 10, and 40 Years (top to bottom, respectively) 

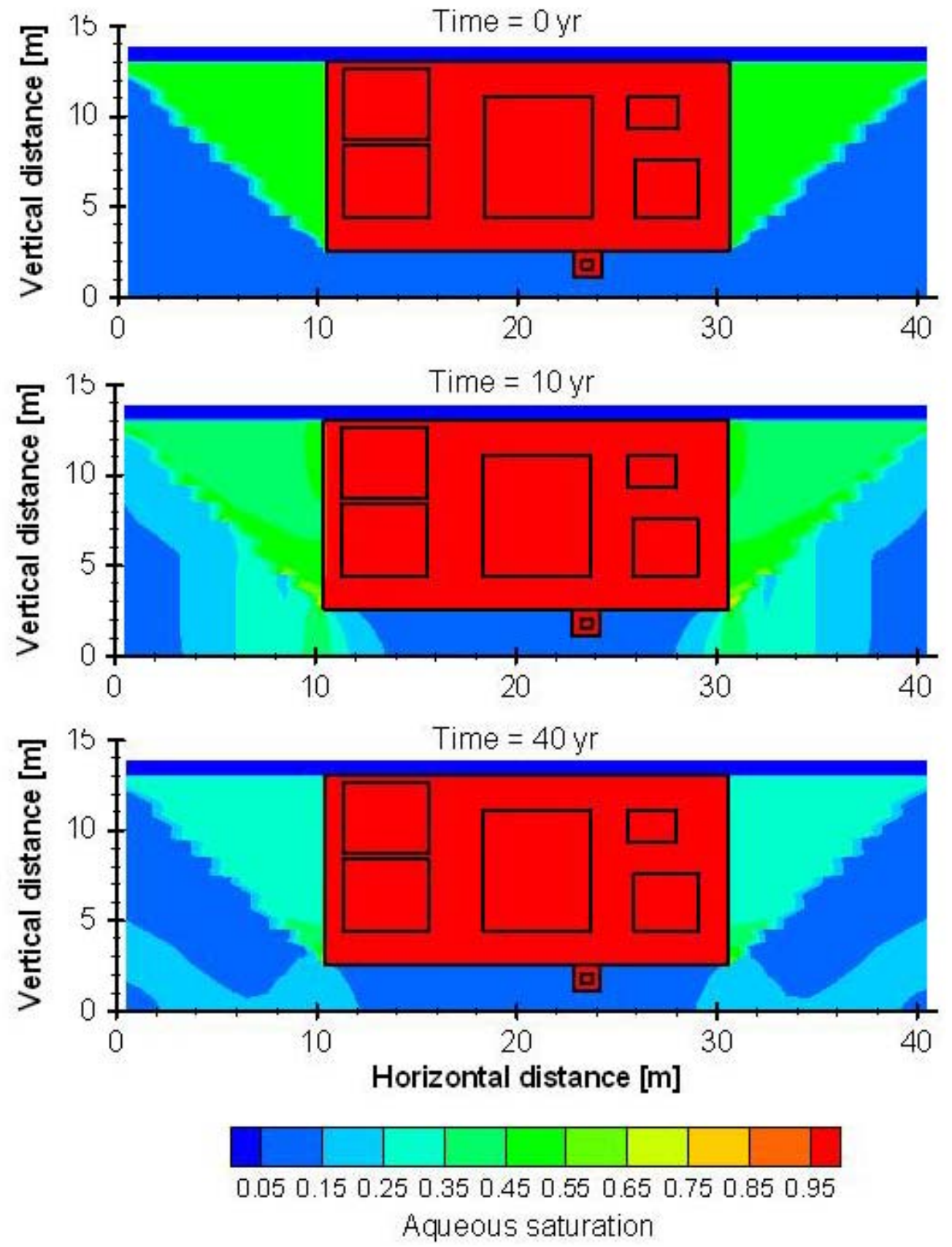

Figure 4. Simulated Aqueous Saturation Distributions at 0 (initial condition), 10, and 40 Years (top to bottom, respectively)

into the surrounding soil environment. Reducing water infiltration rates by placing covers over the canyon buildings will mitigate the longer-term transport of contaminants through the vadose zone and into the ground water. 


\subsection{Conclusions}

The STOMP code was used to simulate transport of selected radionuclides out of a canyon building, representative of the 221-U facility after decommissioning, for a period of 40 years. Simulation results indicate that none of the selected radionuclides that were modeled migrated beyond the concrete structure of the facility during the 40-year period of interest. Jacques (2001) identified other potential contaminants in the 221-U facility that were not modeled, however, including kerosene, phenol, and various metals. Modeling of these contaminants was beyond the scope of this preliminary effort due to increased complexity.

Simulation results indicate that contaminant release from the canyon buildings will be diffusion controlled at early times. Advection is expected to become much more important at later times, after contaminants have diffused out of the facility and into the surrounding soil environment. After contaminants have diffused out of the facility, surface infiltration covers will become very important for mitigating further transport of contaminants in the underlying vadose zone and groundwater. 


\subsection{References}

Jacques, I. D. 2001. Final data report for the 221-U facility characterization. BHI-01565, Rev. 0., Bechtel Hanford, Inc.

Kemper, W. D., and J. C. van Schaik. 1966. Diffusion of salts in clay-water systems. Soil Sci. Am. Proc. 30:534-540.

Kincaid, C. T., et al. 1995. Performance assessment of grouted double-shell tank waste disposal at Hanford, WHC-SD-WM-EE-004, Rev. 1, Westinghouse Hanford Company, Richland, Washington.

Lide, D. R. (ed.). 1996. Handbook of Chemistry and Physics, CRC Press, Inc., Boca Raton, Florida.

Mattigod, S. V., P. F. Martin, G. A. Whyatt, K. E. Schwab, R. J. Serne, and M. I. Wood. 2001. Diffusion and leaching of selected radionuclides (iodine-129, technicium-99, and uranium) through category 3 waste encasement concrete and soil fill material. PNNL-13639, Pacific Northwest National Laboratory, Richland, Washington.

Meyer, P. D., and R. J. Serne. 1999. Near-field hydrology data package for the immobilized low-activity waste performance assessment. PNNL-13035, Pacific Northwest National Laboratory, Richland, Washington.

Rockhold, M. L., M. J. Fayer, and P. R. Heller. 1993. Physical and hydraulic properties of sediments and engineered materials associated with grouted double-shell tank waste disposal at Hanford. PNL-8813, Pacific Northwest Laboratory, Richland, Washington.

Rockhold, M. L., M. J. Fayer, C. T. Kincaid, and G. W. Gee. 1995. Estimation of natural groundwater recharge for the performance assessment of a low-level waste disposal facility at the Hanford Site.

PNL-10508, Pacific Northwest National Laboratory, Richland, Washington.

White, M. D., M. Oostrom. 1996. STOMP - Subsurface Transport Over Multiple Phases, Theory Guide. PNNL-11217, Pacific Northwest National Laboratory, Richland, Washington.

White, M. D., M. Oostrom. 2003. STOMP - Subsurface Transport Over Multiple Phases, Version 3.1, User’s Guide. PNNL-14478, Pacific Northwest National Laboratory, Richland, Washington.

Whiting, D., and A. Walitt (eds). 1988. Permeability of concrete. SP-108, American Concrete Institute, Detroit, Michigan. 
Appendix A

Radionuclide Inventories Used for Initial Conditions in STOMP Simulations 


\section{Appendix A}

\section{Radionuclide Inventories Used for Initial Conditions in STOMP Simulations}

Table A.1. Assumed Initial Radionuclide Inventory in Process Cell Grout

\begin{tabular}{|c|c|c|c|}
\hline Radionuclide & $\mathbf{p C i} / \mathbf{g}$ & $\mathbf{g} / \mathbf{g}$ & $\mathbf{~ k g} / \mathbf{m}^{\mathbf{3}}$ \\
\hline${ }^{60} \mathrm{Co}$ & $4.569 \mathrm{E}+05$ & $4.039 \mathrm{E}-10$ & $9.694 \mathrm{E}-07$ \\
\hline${ }^{89 / 90} \mathrm{Sr}$ & $4.351 \mathrm{E}+07$ & $3.186 \mathrm{E}-07$ & $7.647 \mathrm{E}-04$ \\
\hline${ }^{137} \mathrm{Cs}$ & $3.150 \mathrm{E}+07$ & $3.645 \mathrm{E}-07$ & $8.749 \mathrm{E}-04$ \\
\hline${ }^{154} \mathrm{Eu}$ & $2.559 \mathrm{E}+02$ & $9.471 \mathrm{E}-13$ & $2.273 \mathrm{E}-09$ \\
\hline${ }^{232} \mathrm{Th}$ & $3.227 \mathrm{E}+01$ & $2.934 \mathrm{E}-04$ & $7.041 \mathrm{E}-01$ \\
\hline${ }^{234} \mathrm{U}$ & $1.765 \mathrm{E}+04$ & $2.832 \mathrm{E}-06$ & $6.797 \mathrm{E}-03$ \\
\hline${ }^{235} \mathrm{U}$ & $6.185 \mathrm{E}+03$ & $2.864 \mathrm{E}-03$ & $6.874 \mathrm{E}+00$ \\
\hline${ }^{238} \mathrm{U}$ & $1.310 \mathrm{E}+05$ & $3.893 \mathrm{E}-01$ & $9.343 \mathrm{E}+02$ \\
\hline${ }^{238} \mathrm{Pu}$ & $1.197 \mathrm{E}+01$ & $7.000 \mathrm{E}-13$ & $1.680 \mathrm{E}-09$ \\
\hline${ }^{239} \mathrm{Pu}$ & $2.805 \mathrm{E}+05$ & $4.526 \mathrm{E}-06$ & $1.086 \mathrm{E}-02$ \\
\hline${ }^{240} \mathrm{Pu}$ & $2.242 \mathrm{E}+05$ & $9.848 \mathrm{E}-07$ & $2.364 \mathrm{E}-03$ \\
\hline${ }^{237} \mathrm{~Np}$ & $2.095 \mathrm{E}-01$ & $2.975 \mathrm{E}-10$ & $7.140 \mathrm{E}-07$ \\
\hline${ }^{241} \mathrm{Am}$ & $2.209 \mathrm{E}+05$ & $6.443 \mathrm{E}-08$ & $1.546 \mathrm{E}-04$ \\
\hline
\end{tabular}

Table A.2. Assumed Initial Radionuclide Inventory in Process Cell Concrete Floor

\begin{tabular}{|c|c|c|c|}
\hline Radionuclide & $\mathbf{p C i} / \mathbf{g}$ & $\mathbf{g} / \mathbf{g}$ & $\mathbf{~ k g} / \mathbf{m}^{\mathbf{3}}$ \\
\hline${ }^{60} \mathrm{Co}$ & 0.22 & $1.945 \mathrm{E}-16$ & $4.785 \mathrm{E}-13$ \\
\hline${ }^{89 / 90} \mathrm{Sr}$ & 64,600 & $4.731 \mathrm{E}-10$ & $1.164 \mathrm{E}-06$ \\
\hline${ }^{137} \mathrm{Cs}$ & 60,200 & $6.966 \mathrm{E}-10$ & $1.714 \mathrm{E}-06$ \\
\hline${ }^{154} \mathrm{Eu}$ & 37 & $1.369 \mathrm{E}-13$ & $3.368 \mathrm{E}-10$ \\
\hline${ }^{230} \mathrm{Th}$ & 64 & $3.107 \mathrm{E}-09$ & $7.643 \mathrm{E}-06$ \\
\hline${ }^{234} \mathrm{U}$ & 1.4 & $2.247 \mathrm{E}-10$ & $5.527 \mathrm{E}-07$ \\
\hline${ }^{235} \mathrm{U}$ & 0.05 & $2.316 \mathrm{E}-08$ & $5.696 \mathrm{E}-05$ \\
\hline${ }^{238} \mathrm{U}$ & 1.6 & $4.754 \mathrm{E}-06$ & $1.170 \mathrm{E}-02$ \\
\hline${ }^{238} \mathrm{Pu}$ & 22 & $1.286 \mathrm{E}-12$ & $3.164 \mathrm{E}-09$ \\
\hline${ }^{239} \mathrm{Pu}$ & 224 & $3.613 \mathrm{E}-09$ & $8.889 \mathrm{E}-06$ \\
\hline${ }^{240} \mathrm{Pu}$ & 96 & $4.216 \mathrm{E}-10$ & $1.037 \mathrm{E}-06$ \\
\hline${ }^{237} \mathrm{~Np}$ & 0.13 & $1.846 \mathrm{E}-10$ & $4.541 \mathrm{E}-07$ \\
\hline${ }^{241} \mathrm{Am}$ & 181 & $5.278 \mathrm{E}-11$ & $1.298 \mathrm{E}-07$ \\
\hline
\end{tabular}


Table A.3. Assumed Initial Radionuclide Inventory in Ventilation Tunnel Grout

\begin{tabular}{|c|c|c|c|}
\hline Radionuclide & $\mathbf{p C i} / \mathbf{g}$ & $\mathbf{g} / \mathbf{g}$ & $\mathbf{~ k g} / \mathbf{m}^{\mathbf{3}}$ \\
\hline${ }^{89 / 90} \mathrm{Sr}$ & $1.151 \mathrm{E}+04$ & $8.430 \mathrm{E}-11$ & $2.023 \mathrm{E}-07$ \\
\hline${ }^{137} \mathrm{Cs}$ & $8.344 \mathrm{E}+02$ & $9.656 \mathrm{E}-12$ & $2.317 \mathrm{E}-08$ \\
\hline${ }^{234} \mathrm{U}$ & $9.189 \mathrm{E}-01$ & $1.475 \mathrm{E}-10$ & $3.539 \mathrm{E}-07$ \\
\hline${ }^{235} \mathrm{U}$ & $6.337 \mathrm{E}-02$ & $2.935 \mathrm{E}-08$ & $7.044 \mathrm{E}-05$ \\
\hline${ }^{238} \mathrm{U}$ & $1.003 \mathrm{E}+00$ & $2.982 \mathrm{E}-06$ & $7.156 \mathrm{E}-03$ \\
\hline${ }^{238} \mathrm{Pu}$ & $1.373 \mathrm{E}-01$ & $8.026 \mathrm{E}-15$ & $1.926 \mathrm{E}-11$ \\
\hline${ }^{239} \mathrm{Pu}$ & $7.171 \mathrm{E}+00$ & $1.157 \mathrm{E}-10$ & $2.776 \mathrm{E}-07$ \\
\hline${ }^{240} \mathrm{Pu}$ & $3.073 \mathrm{E}+00$ & $1.350 \mathrm{E}-11$ & $3.240 \mathrm{E}-08$ \\
\hline${ }^{237} \mathrm{~Np}$ & $2.693 \mathrm{E}-02$ & $3.824 \mathrm{E}-11$ & $9.177 \mathrm{E}-08$ \\
\hline${ }^{241} \mathrm{Am}$ & $1.780 \mathrm{E}+00$ & $5.189 \mathrm{E}-13$ & $1.245 \mathrm{E}-09$ \\
\hline
\end{tabular}

Table A.4. Assumed Initial Radionuclide Inventory in Drain Header Grout

\begin{tabular}{|c|c|c|}
\hline Radionuclide & $\boldsymbol{\mu g} / \mathbf{g}$ & $\mathbf{~ k g} / \mathbf{m}^{\mathbf{3}}$ \\
\hline${ }^{60} \mathrm{Co}$ & $5.800 \mathrm{E}+01$ & $1.392 \mathrm{E}-01$ \\
\hline${ }^{89 / 90} \mathrm{Sr}$ & $1.489 \mathrm{E}+05$ & $3.573 \mathrm{E}+02$ \\
\hline${ }^{137} \mathrm{Cs}$ & $6.839 \mathrm{E}+05$ & $1.641 \mathrm{E}+03$ \\
\hline${ }^{154} \mathrm{Eu}$ & $1.353 \mathrm{E}+03$ & $3.246 \mathrm{E}+00$ \\
\hline${ }^{238} \mathrm{U}$ & $2.251 \mathrm{E}+01$ & $5.402 \mathrm{E}-02$ \\
\hline${ }^{238} \mathrm{Pu}$ & $6.449 \mathrm{E}+01$ & $1.548 \mathrm{E}-01$ \\
\hline${ }^{239} \mathrm{Pu}$ & $1.082 \mathrm{E}+03$ & $2.596 \mathrm{E}+00$ \\
\hline${ }^{240} \mathrm{Pu}$ & $4.636 \mathrm{E}+02$ & $1.113 \mathrm{E}+00$ \\
\hline${ }^{241} \mathrm{Am}$ & $7.488 \mathrm{E}+02$ & $1.797 \mathrm{E}+00$ \\
\hline \multicolumn{2}{|c}{} \\
\hline
\end{tabular}


Appendix B

Physical, Hydraulic, and Transport Parameters Used for STOMP Simulations 


\section{Appendix B}

\section{Physical, Hydraulic, and Transport Parameters Used for STOMP Simulations}

Table B.1. Physical and Hydraulic Properties of Sediments and Engineered Materials

\begin{tabular}{|c|c|c|c|c|c|c|c|}
\hline Material & $K_{s}[\mathrm{~cm} / \mathrm{s}]$ & $\theta_{s}$ & $\theta_{r}$ & $\alpha[1 / \mathrm{cm}]$ & $n$ & $\rho_{b}\left[\mathrm{~g} / \mathrm{cm}^{3}\right]$ & $\rho_{p}\left[\mathrm{~g} / \mathrm{cm}^{3}\right]$ \\
\hline Hanford sand & $1.55 \mathrm{e}-3$ & 0.420 & 0.023 & 0.1943 & 1.868 & 1.578 & 2.72 \\
\hline Compacted soil & $1.80 \mathrm{e}-6$ & 0.353 & 0.003 & 0.0121 & 1.370 & 1.760 & 2.72 \\
\hline Backfill soil & $1.91 \mathrm{e}-3$ & 0.316 & 0.049 & 0.035 & 1.720 & 1.889 & 2.76 \\
\hline Concrete & $1.33 \mathrm{e}-9$ & 0.067 & 0.000 & $3.87 e-5$ & 1.290 & 2.453 & 2.63 \\
\hline Grout & $1.47 \mathrm{e}-8$ & 0.087 & 0.000 & $1.08 \mathrm{e}-5$ & 1.650 & 2.400 & 2.63 \\
\hline Surface gravel & $1.85 \mathrm{e}-0$ & 0.518 & 0.014 & 3.54 & 2.660 & 1.350 & 2.80 \\
\hline
\end{tabular}

Table B.2. Atomic Weights and Half-Lives of Modeled Radionuclides

\begin{tabular}{|l|c|l|}
\hline Radionuclide & Atomic weight [g/mol] & \multicolumn{1}{|c|}{$\mathbf{t}_{\mathbf{1} / \mathbf{2}}$ [yr] } \\
\hline${ }^{60} \mathrm{Co}$ & 59.93 & 5.27 \\
\hline${ }^{90} \mathrm{Sr}$ & 89.91 & 29.1 \\
\hline${ }^{137} \mathrm{Cs}$ & 136.91 & 30.2 \\
\hline${ }^{154} \mathrm{Eu}$ & 153.92 & 8.59 \\
\hline${ }^{230} \mathrm{Th}$ & 230.03 & $7.54 \mathrm{e}+04$ \\
\hline${ }^{232} \mathrm{Th}$ & 232.04 & $1.40 \mathrm{e}+10$ \\
\hline${ }^{234} \mathrm{U}$ & 234.04 & $2.45 \mathrm{e}+05$ \\
\hline${ }^{235} \mathrm{U}$ & 235.04 & $7.04 \mathrm{e}+08$ \\
\hline${ }^{237} \mathrm{~Np}$ & 237.05 & $2.14 \mathrm{e}+06$ \\
\hline${ }^{238} \mathrm{U}$ & 238.05 & $4.46 \mathrm{e}+09$ \\
\hline${ }^{238} \mathrm{Pu}$ & 238.05 & 87.7 \\
\hline${ }^{239} \mathrm{Pu}$ & 239.05 & $2.41 \mathrm{e}+04$ \\
\hline${ }^{240} \mathrm{Pu}$ & 240.05 & $6.54 \mathrm{e}+03$ \\
\hline${ }^{241} \mathrm{Am}$ & 241.06 & $4.32 \mathrm{e}+02$ \\
\hline
\end{tabular}


Table B.3. Diffusion and Sorption Coefficients for Hanford Sand, Backfill Material, and Compacted Soil

\begin{tabular}{|l|c|c|c|c|}
\hline Radionuclide & $\boldsymbol{K}_{\boldsymbol{d}}\left[\mathbf{m}^{\mathbf{3}} / \mathbf{k g}\right]$ & $\boldsymbol{D}_{\boldsymbol{a} \boldsymbol{b}}\left[\mathbf{m}^{\mathbf{2}} / \mathbf{s} \boldsymbol{]}\right.$ & $\boldsymbol{a}$ & $\boldsymbol{b}$ \\
\hline${ }^{60} \mathrm{Co}$ & 0.003 & $2.50 \mathrm{e}-9$ & 0.005 & 10 \\
\hline${ }^{90} \mathrm{Sr}$ & 0.003 & $2.50 \mathrm{e}-9$ & 0.005 & 10 \\
\hline${ }^{137} \mathrm{Cs}$ & 0.003 & $2.50 \mathrm{e}-9$ & 0.005 & 10 \\
\hline${ }^{154} \mathrm{Eu}$ & 0.021 & $2.50 \mathrm{e}-9$ & 0.005 & 10 \\
\hline${ }^{230} \mathrm{Th}$ & 0.021 & $2.50 \mathrm{e}-9$ & 0.005 & 10 \\
\hline${ }^{232} \mathrm{Th}$ & 0.021 & $2.50 \mathrm{e}-9$ & 0.005 & 10 \\
\hline${ }^{234} \mathrm{U}$ & 0.000 & $2.50 \mathrm{e}-9$ & 0.005 & 10 \\
\hline${ }^{235} \mathrm{U}$ & 0.000 & $2.50 \mathrm{e}-9$ & 0.005 & 10 \\
\hline${ }^{237} \mathrm{~Np}$ & 0.003 & $2.50 \mathrm{e}-9$ & 0.005 & 10 \\
\hline${ }^{238} \mathrm{U}$ & 0.000 & $2.50 \mathrm{e}-9$ & 0.005 & 10 \\
\hline${ }^{238} \mathrm{Pu}$ & 0.021 & $2.50 \mathrm{e}-9$ & 0.005 & 10 \\
\hline${ }^{239} \mathrm{Pu}$ & 0.021 & $2.50 \mathrm{e}-9$ & 0.005 & 10 \\
\hline${ }^{240} \mathrm{Pu}$ & 0.021 & $2.50 \mathrm{e}-9$ & 0.005 & 10 \\
\hline${ }^{241} \mathrm{Am}$ & 0.021 & $2.50 \mathrm{e}-9$ & 0.005 & 10 \\
\hline
\end{tabular}

Table B.4. Diffusion and Sorption Coefficients for Concrete

\begin{tabular}{|l|c|c|l|l|}
\hline Radionuclide & $\boldsymbol{K}_{\boldsymbol{d}}\left[\mathbf{m}^{\mathbf{3}} / \mathbf{k g}\right]$ & $\boldsymbol{D}_{\boldsymbol{a b}}\left[\mathbf{\mathbf { m } ^ { 2 }} / \mathbf{s}\right]$ & $\boldsymbol{a}$ & $\boldsymbol{b}$ \\
\hline${ }^{60} \mathrm{Co}$ & 0.125 & $5.0 \mathrm{e}-12$ & 1 & 0 \\
\hline${ }^{90} \mathrm{Sr}$ & 0.125 & $5.0 \mathrm{e}-12$ & 1 & 0 \\
\hline${ }^{137} \mathrm{Cs}$ & 0.125 & $5.0 \mathrm{e}-12$ & 1 & 0 \\
\hline${ }^{154} \mathrm{Eu}$ & 2.625 & $5.0 \mathrm{e}-12$ & 1 & 0 \\
\hline${ }^{230} \mathrm{Th}$ & 2.625 & $5.0 \mathrm{e}-12$ & 1 & 0 \\
\hline${ }^{232} \mathrm{Th}$ & 2.625 & $5.0 \mathrm{e}-12$ & 1 & 0 \\
\hline${ }^{234} \mathrm{U}$ & 2.625 & $5.0 \mathrm{e}-12$ & 1 & 0 \\
\hline${ }^{235} \mathrm{U}$ & 2.625 & $5.0 \mathrm{e}-12$ & 1 & 0 \\
\hline${ }^{237} \mathrm{~Np}$ & 0.125 & $5.0 \mathrm{e}-12$ & 1 & 0 \\
\hline${ }^{238} \mathrm{U}$ & 2.625 & $5.0 \mathrm{e}-12$ & 1 & 0 \\
\hline${ }^{238} \mathrm{Pu}$ & 2.625 & $5.0 \mathrm{e}-12$ & 1 & 0 \\
\hline${ }^{239} \mathrm{Pu}$ & 2.625 & $5.0 \mathrm{e}-12$ & 1 & 0 \\
\hline${ }^{240} \mathrm{Pu}$ & 2.625 & $5.0 \mathrm{e}-12$ & 1 & 0 \\
\hline${ }^{241} \mathrm{Am}$ & 2.625 & $5.0 \mathrm{e}-12$ & 1 & 0 \\
\hline
\end{tabular}


Table B.5. Diffusion and Sorption Coefficient for Grout

\begin{tabular}{|l|c|c|l|l|}
\hline Radionuclide & $\boldsymbol{K}_{\boldsymbol{d}}\left[\mathbf{m}^{\mathbf{3}} / \mathbf{k g}\right]$ & $\boldsymbol{D}_{\boldsymbol{a b}}\left[\mathbf{m}^{\mathbf{2}} / \mathbf{s}\right]$ & $\boldsymbol{a}$ & $\boldsymbol{b}$ \\
\hline${ }^{60} \mathrm{Co}$ & 0.125 & $1.0 \mathrm{e}-10$ & 1 & 0 \\
\hline${ }^{90} \mathrm{Sr}$ & 0.125 & $1.0 \mathrm{e}-10$ & 1 & 0 \\
\hline${ }^{137} \mathrm{Cs}$ & 0.125 & $1.0 \mathrm{e}-10$ & 1 & 0 \\
\hline${ }^{154} \mathrm{Eu}$ & 2.625 & $1.0 \mathrm{e}-10$ & 1 & 0 \\
\hline${ }^{230} \mathrm{Th}$ & 2.625 & $1.0 \mathrm{e}-10$ & 1 & 0 \\
\hline${ }^{232} \mathrm{Th}$ & 2.625 & $1.0 \mathrm{e}-10$ & 1 & 0 \\
\hline${ }^{234} \mathrm{U}$ & 2.625 & $1.0 \mathrm{e}-10$ & 1 & 0 \\
\hline${ }^{235} \mathrm{U}$ & 2.625 & $1.0 \mathrm{e}-10$ & 1 & 0 \\
\hline${ }^{237} \mathrm{~Np}$ & 0.125 & $1.0 \mathrm{e}-10$ & 1 & 0 \\
\hline${ }^{238} \mathrm{U}$ & 2.625 & $1.0 \mathrm{e}-10$ & 1 & 0 \\
\hline${ }^{238} \mathrm{Pu}$ & 2.625 & $1.0 \mathrm{e}-10$ & 1 & 0 \\
\hline${ }^{239} \mathrm{Pu}$ & 2.625 & $1.0 \mathrm{e}-10$ & 1 & 0 \\
\hline${ }^{240} \mathrm{Pu}$ & 2.625 & $1.0 \mathrm{e}-10$ & 1 & 0 \\
\hline${ }^{241} \mathrm{Am}$ & 2.625 & $1.0 \mathrm{e}-10$ & 1 & 0 \\
\hline
\end{tabular}

